\title{
Inundated Infrastructure: Jakarta's Failing Hydraulic Infrastructure
}

FRANK SEDLAR

fsedlar@gmail.com, 605 Ogden Ave., Escanaba, MI 49829, USA

Volume 4, 2016

http://dx.doi.org/10.3998/mjs.12333712.0004.004

Jakarta, Indonesia has had an intimate relationship with annual flooding for hundreds of years. However, this yearly inundation is rarely from heavy precipitation alone, but rather from direct human interference in the hydrologic-hydraulic system of Jakarta. The result of this anthropogenic involvement means that flooding in Jakarta rarely follows topographical lines. This is extremely problematic because the hydraulic infrastructure that Jakarta depends on for flood control can only understand "traditional flooding"-flooding that occurs along topographical lines that can be probabilistically predicted from historical data. To illustrate the systematic failure of Jakarta's probabilistic based hydraulic infrastructure, aerial photographs are presented that detail the sites of recent failure that were responsible for flooding throughout Jakarta. As the infrastructure failure is invisible to traditional hydraulic modeling, so too is the consequence of failure when viewed at eye level. The visual understanding of this infrastructural failure is then used as a departure point to discuss new methods to operate the hydraulic infrastructure of not only Jakarta, but also cities around the world.

Jakarta, Indonesia has long had an intimate relationship with annual flooding - an intimate relationship which, over the previous 500 years, has proven difficult to contend with for the Indonesian government, the Dutch colonial government, and even the Tarumanagara Kingdom in the fifth century (Yarista, 2016). At present, 72.7 percent of Jakarta is prone to flooding, threatening the lives of over 983,399 residents, or 10.2 percent of Jakarta's population (Holderness et al., 2015). This threat of flooding arises because of the large amount of water that must 
be drained through Jakarta to the Java Sea, particularly during the yearly Southeast Asian monsoons.

But controlling the flooding has always been a difficult problem for Jakarta due to the fact that the city's flooding rarely follows topographical lines. The record of Jakarta's historical flooding reveals a chronicle of inundation that is the result of anything but intense precipitation and overflowing canals. Rather, the majority of Jakarta's annual flooding has directly resulted from anthropogenic causes. Interferences range from deforestation upstream of Jakarta to mistakenly cutting the power to pump houses to canal walls collapsing because of encroaching settlements. All this human interference in the hydrological-hydraulic system of Jakarta results in flooding occurring where it should not.

This is problematic for controlling Jakarta's flooding because the flood modeling, flood predictions, and operation of the hydraulic infrastructure used to mitigate the flooding can only understand "traditional flooding"-flooding that occurs along topographical lines. As stated in the manual for Jakarta's flood modeling software, JFEWS, "failure of structures or levees is not considered (FMIS Team, 2012)." This suggests there is a disconnect between how the government understands the city's flooding and the reality of the situation.

Hydrologically speaking, "understanding flooding that occurs along topographical lines" refers to the probabilistic way in which flooding is traditionally predicted and modeled. Flood models seek to correlate historical rainfall and flood height data to predict future flooding. The anticipated flow of water then dictates the operation of pieces of hydraulic infrastructure-pump houses, floodgates, and reservoirs. This is a problematic approach when there is so little historical relationship between the causes of flooding events in Jakarta (Table 1).

Confirming the errors of operating hydraulic infrastructure in a probabilistic manner are the physical pieces of infrastructure scattered throughout Jakarta. Despite 500 years worth of hydraulic infrastructure investment, construction, and maintenance, Jakarta's flooding has only gotten worse. In 2002 Jakarta experienced its worst flooding ever. This severity was eclipsed five years later by the 2007 flooding. Severe flooding has continued to plague the city in 2013 and again in 2014. This new hydraulic infrastructure will have limited effect in mitigating Jakarta's future flooding until it can understand flooding that occurs beyond topographical lines.

To illustrate the systematic failure of Jakarta's probabilistic based hydraulic infrastructure, the following aerial photographs detail the sites of recent failure that were responsible for flooding in Jakarta (Figures 1-8). As the infrastructure failure is 
Table 1. Jakarta's Historical Flooding.

Jakarta has experienced considerable flooding throughout its history. Flooding that has often resulted from infrastructural failure rather than intense precipitation, particularly in 1714, 1918, 2002, 2013, and 2014. This data also shows that the frequency of severe flooding (the return period) in Jakarta is decreasing. Historically, the return period of a 100-year flood was 17 years. This return period is now less than five years. Analysis of (limited) rainfall and streamflow patterns also confirm this.

Year Affect

1699 Ciliwung River floods old Batavia after Mount Salak erupts.

1714 Ciliwung River overflows after clearing forest areas in Puncak.

1854 New Batavia is under a meter of water, caused by the raging Ciliwung.

1878 Rain falls for 40 straight days. All of Batavia and Omelanden severely flooded.

1918 Extensive Flooding. The Dutch colonial government begins work on the Western Flood Canal.

1942 The West Banjir Canal is completed, but Jakarta still floods.

1996 A flood sweeps through the capital.

2002 The Dartmouth Flood Observatory notes the flooding as the largest flood in Jakarta's history.

2007 The greatest flood to hit Jakarta in the last three centuries.

2013 Jakarta's CBD floods after a 30-meter portion of the West Flood Canal collapses.

2014 Electricity is unexpectedly cut off to the Waduk Pluit Pump House during high tide.

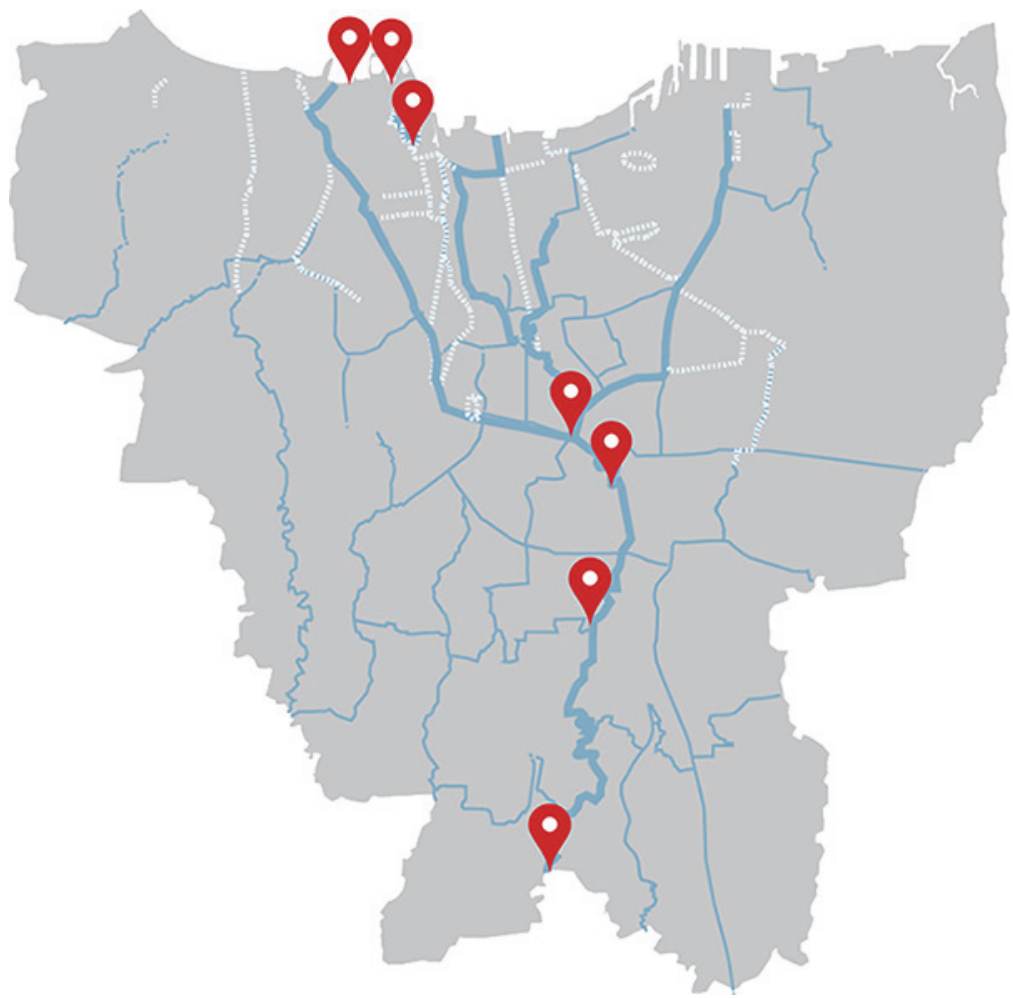

Figure 1. Locations of Aerial Photographs.

The seven photos shown here correspond to sites of infrastructural failure and subsequent flooding that did not occur along topographical lines, all situated along the Ciliwung River. Although 13 rivers and 1900 kilometers of canals drain through Jakarta, the Ciliwung River flows through the heart of Jakarta, has numerous pieces of hydraulic infrastructure along its length, and is the most prone to flooding. 


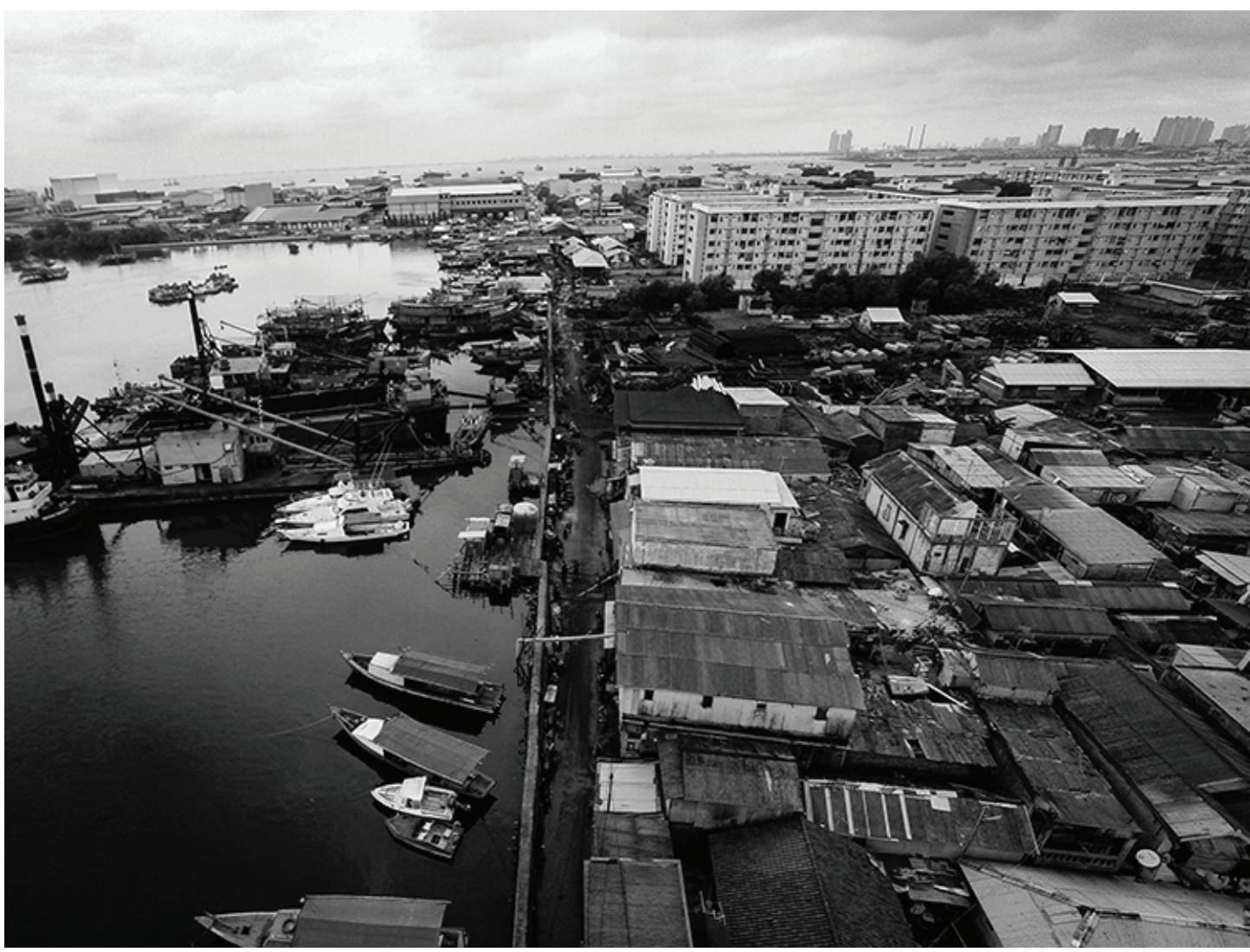

Figure 2. North Jakarta Seawall.

With 30 percent of Jakarta situated at or below sea level, the effects of global sea level rise of 3 $\mathrm{mm} /$ year presents a severe problem for the city (Baker, 2012). The current seawall shown here was built in the 1980s. Today the hulls of ships on the other side are nearly level with the top of the seawall. Approximately twice per week the Java Sea tops the seawall and floods areas of Muara Baru and Muara Angke (Haryanto, 2016).

invisible to traditional hydraulic modeling, so too is the consequence of failure when viewed at eye level. These pieces of hydraulic infrastructure were deliberately photographed during the dry season (April-November) to demonstrate that failure from anthropogenic interference is a distinct possibility even when rain is not falling.

The systematic failure of probabilistic based hydraulic infrastructure questions how we approach flooding in developing megacities — cities with populations larger than 10 million (Taubenböck et al., 2012). In many ways an intimate relationship to annual flooding along with a history of ineffective, probabilistic based hydraulic infrastructure is not unique to Jakarta. Across the Southeast, South, and Mainland Asian region there are currently 20 megacities (Desa, 2011). Of these megacities, 14 are situated in river deltas and 18 have experienced flooding in the past decade 


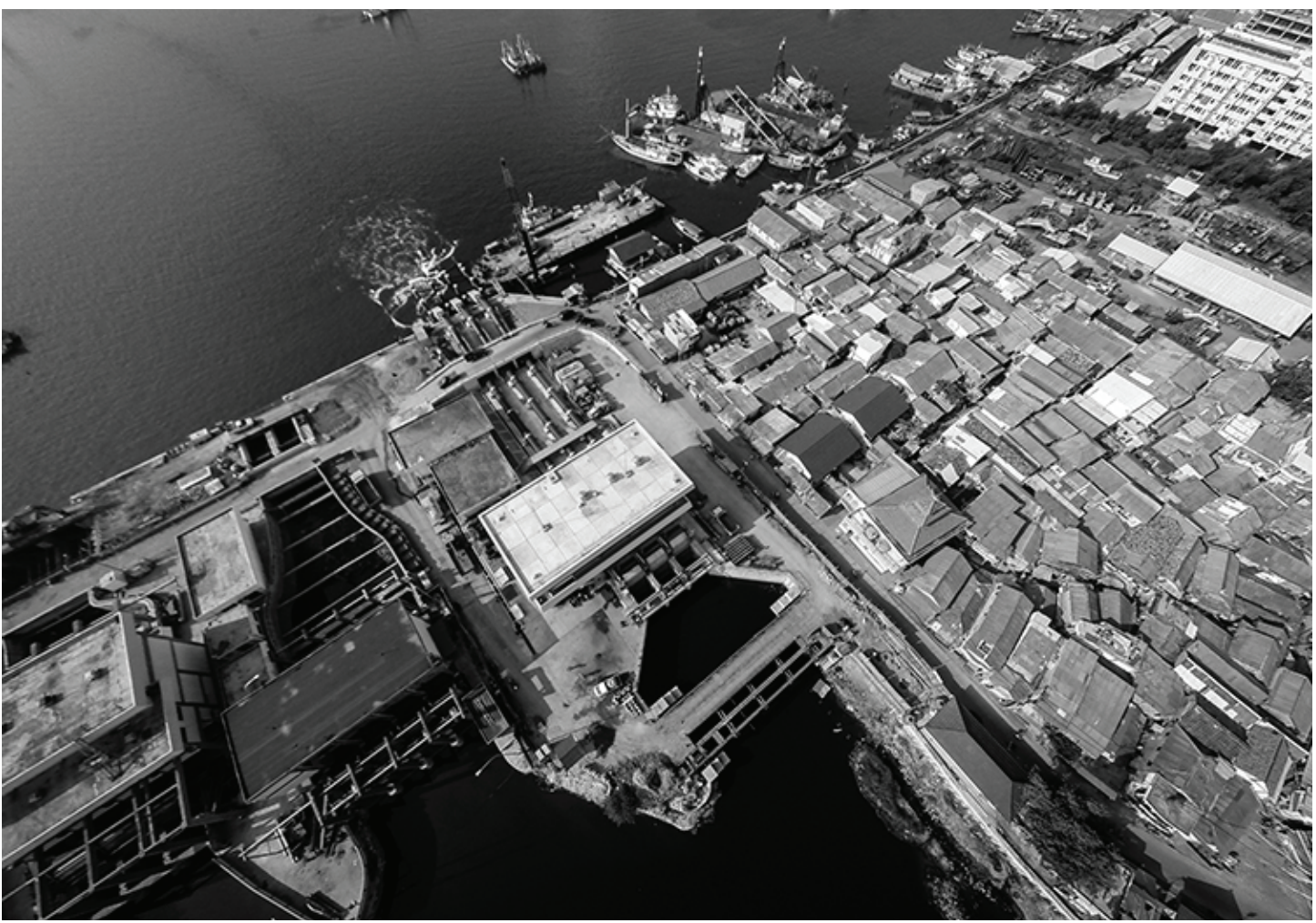

Figure 3. Waduk Pluit Pump House.

The Waduk Pluit Pump House shown here is responsible for pumping the majority of the Ciliwung River over the North Jakarta Seawall into the Java Sea. During the 2014 flooding, the state-owned electric company PLN inadvertently shut off the electricity to the Waduk Pluit Pump House in North Jakarta (Tambun, 2015). The shut-off coincided with high tide, leading to most of North Jakarta being flooded.

(Ceola et al., 2014) (Brakenridge et al., 2006). The increased threat of flooding because of climate change will only make the inevitable hydraulic infrastructural failure more acute.

Critics will argue that with better data and more models and infrastructure, future flooding can be mitigated. This argument ignores the results of 500 years of ineffective, probabilistic based flood mitigation schemes in Jakarta and, more broadly, the reality of developing megacities. The assumption that in these hypercomplex cities flooding can simply be modeled, predicted, and then engineered away is problematic. Amidst rapid urbanization, changing weather patterns, and soaring hydraulic infrastructure costs, simply building the walls of our concrete hydraulic infrastructure higher is only an expensive concrete band aid in addressing a megacity's flooding. 


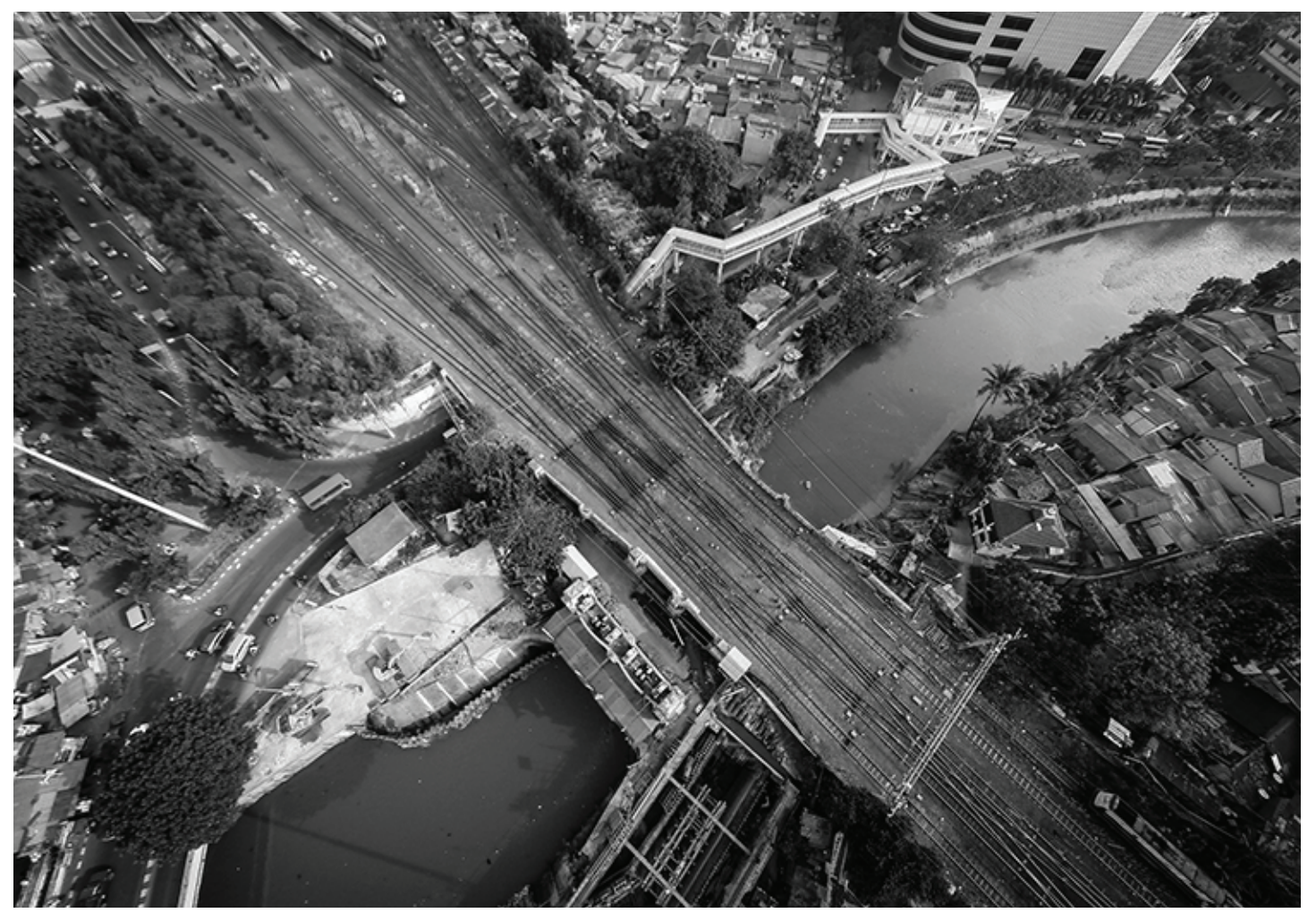

Figure 4. The Manggarai Floodgates.

The Manggarai Floodgates in central Jakarta divert the Ciliwung River to the left and the right of the central business district. The original gates—built in 1917 as part of the Dutch colonial government's van Breen Plan for mitigating the flooding-still stand today (Turpin et al., 2013). Unsurprisingly, the gates are heavily over capacity. In 2013 opening the overworked Manggarai floodgates to lessen inundation in other parts of the city inadvertently flooded the president's palace (Detik, 2013). 


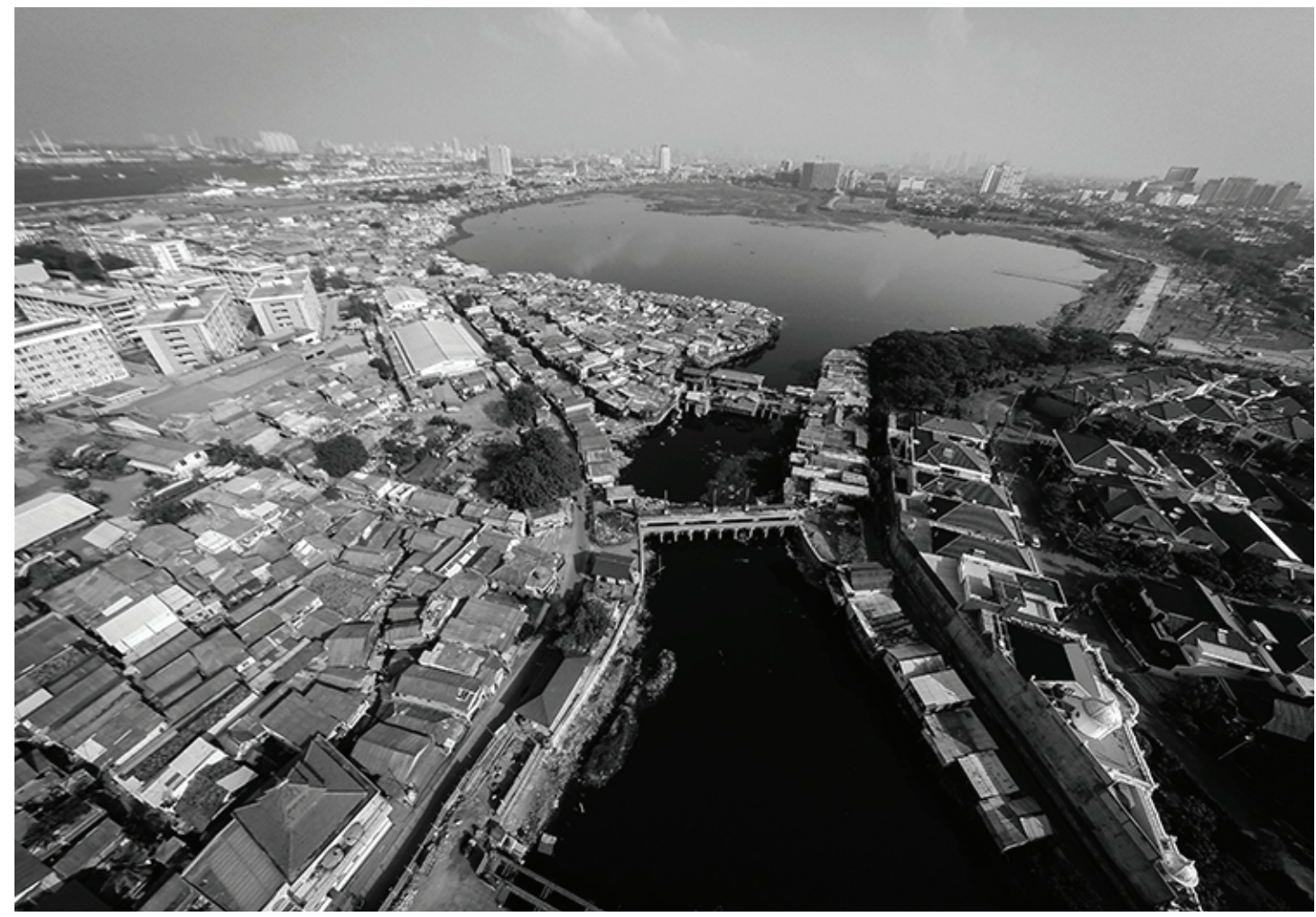

Figure 5. The Waduk Pluit Flood Reservoir.

Before the Ciliwung River can be pumped over the North Jakarta seawall, it must first be pooled into a flood reservoir behind the Waduk Pluit pump house. However, years of accumulated garbage and sedimentation have severely depleted the capacity of the Pluit reservoir to handle floodwaters. It's estimated that this reservoir has lost upward of 70 percent of its capacity, greatly increasing the chance of flooding in surrounding areas during heavy rains (Inundation 3 ). 


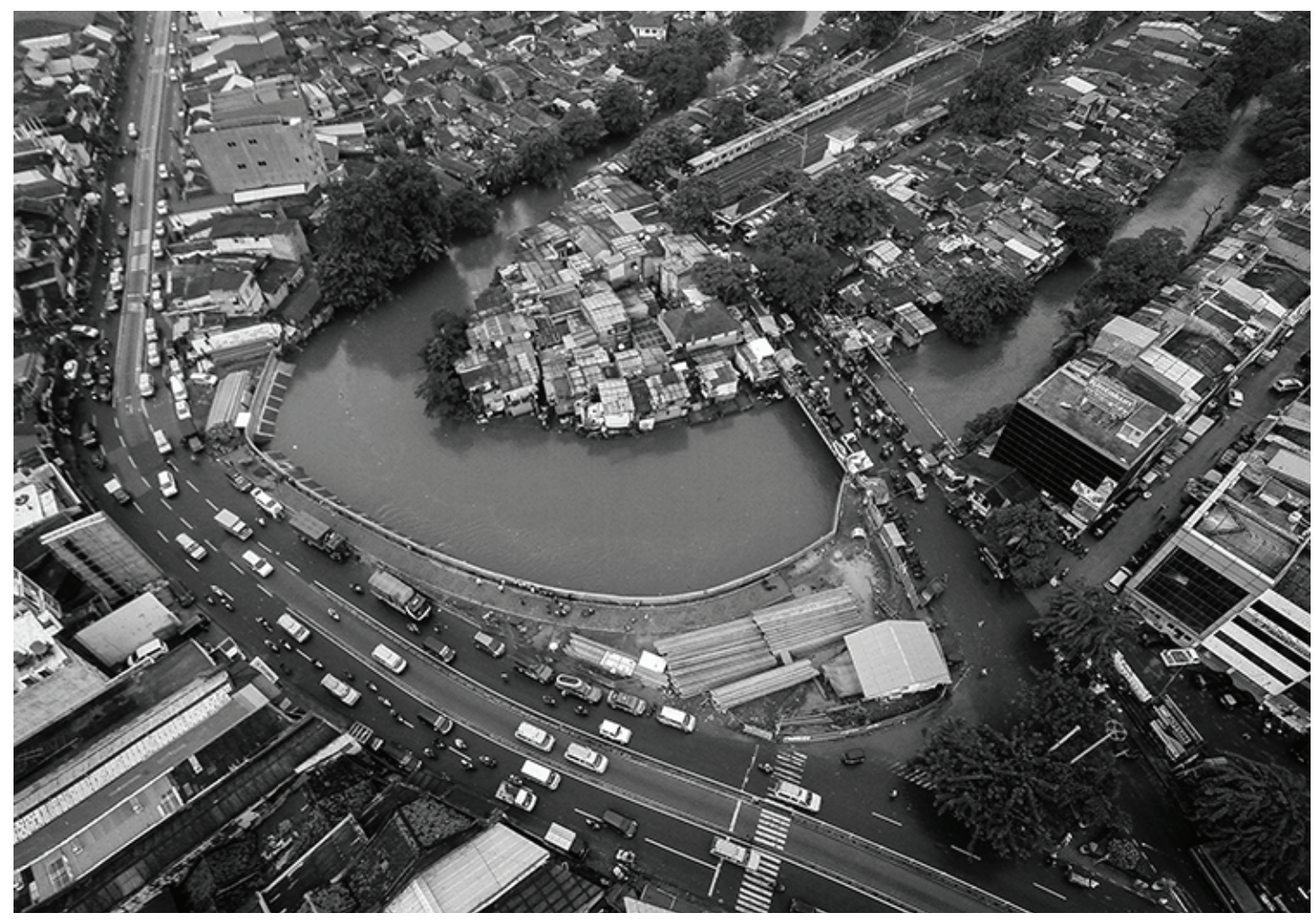

Figure 6. Kampung Bukit Duri.

Over the previous 50 years, Jakarta has urbanized faster than anywhere else on the planet. This rapid development has led to numerous land rights issues where informal settlements are cleared to make way for developments. The evicted persons are then left to settle along the canals and reservoirs - the last undeveloped areas of Jakarta. Unfortunately these informal settlements prevent maintenance on the canals. In 2013, a 30-meter section of the West Flood Canal collapsed, leading to severe flooding throughout Jakarta's central business district (Nirmala, 2013). 


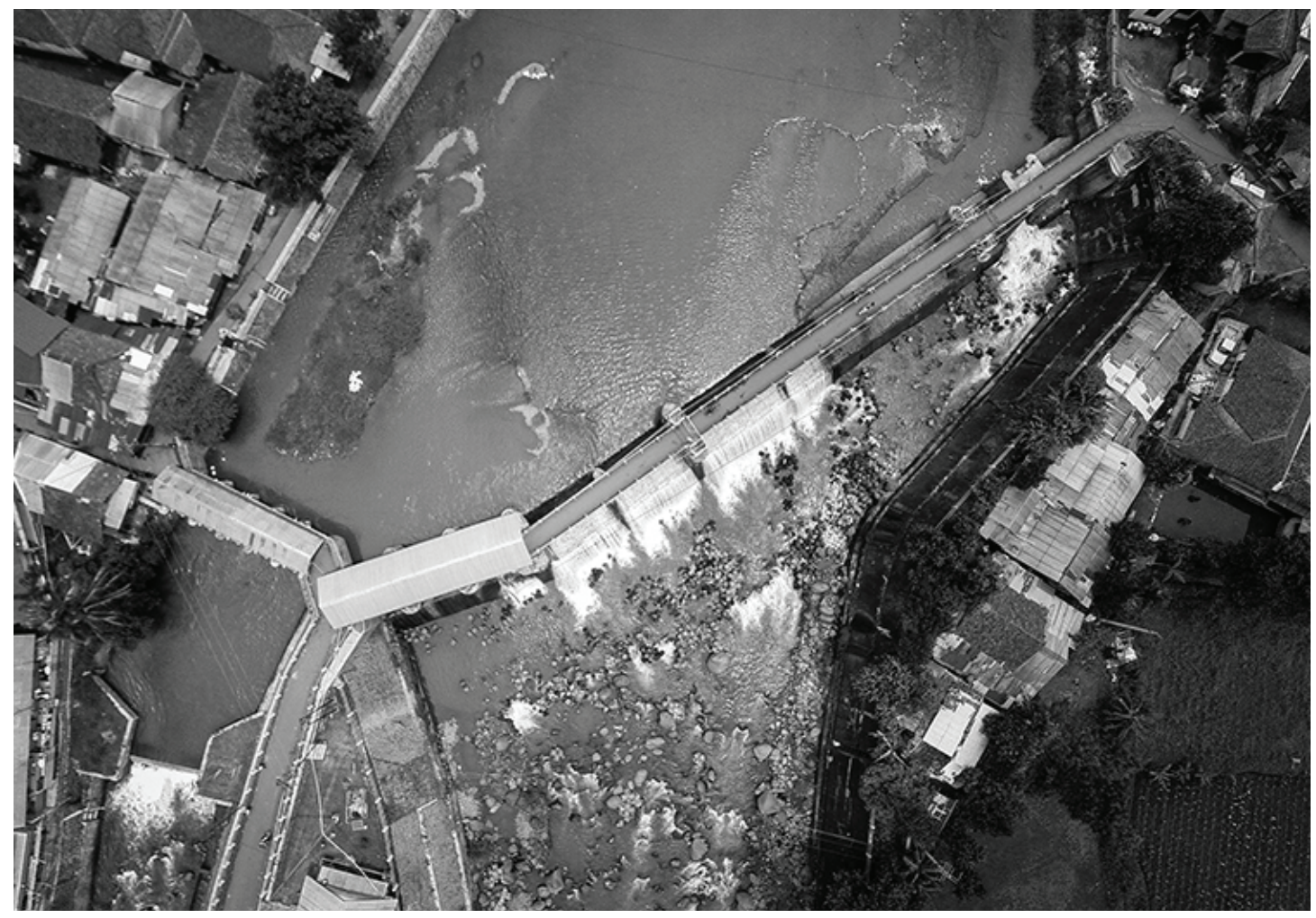

Figure 7. Katulampa Floodgates.

The Katulampa Floodgates upstream along the Ciliwung River in Bogor are the first hydraulic controls for Jakarta. When runoff from the nearby mountains cause the water level at the Katulampa floodgates to rise, Jakarta has approximately 3.5 hours until water levels in the city begin to rise. As far back as 1714, deforestation in Bogor has had a direct, negative impact on the flooding experienced in Jakarta (Adams, 2016). 


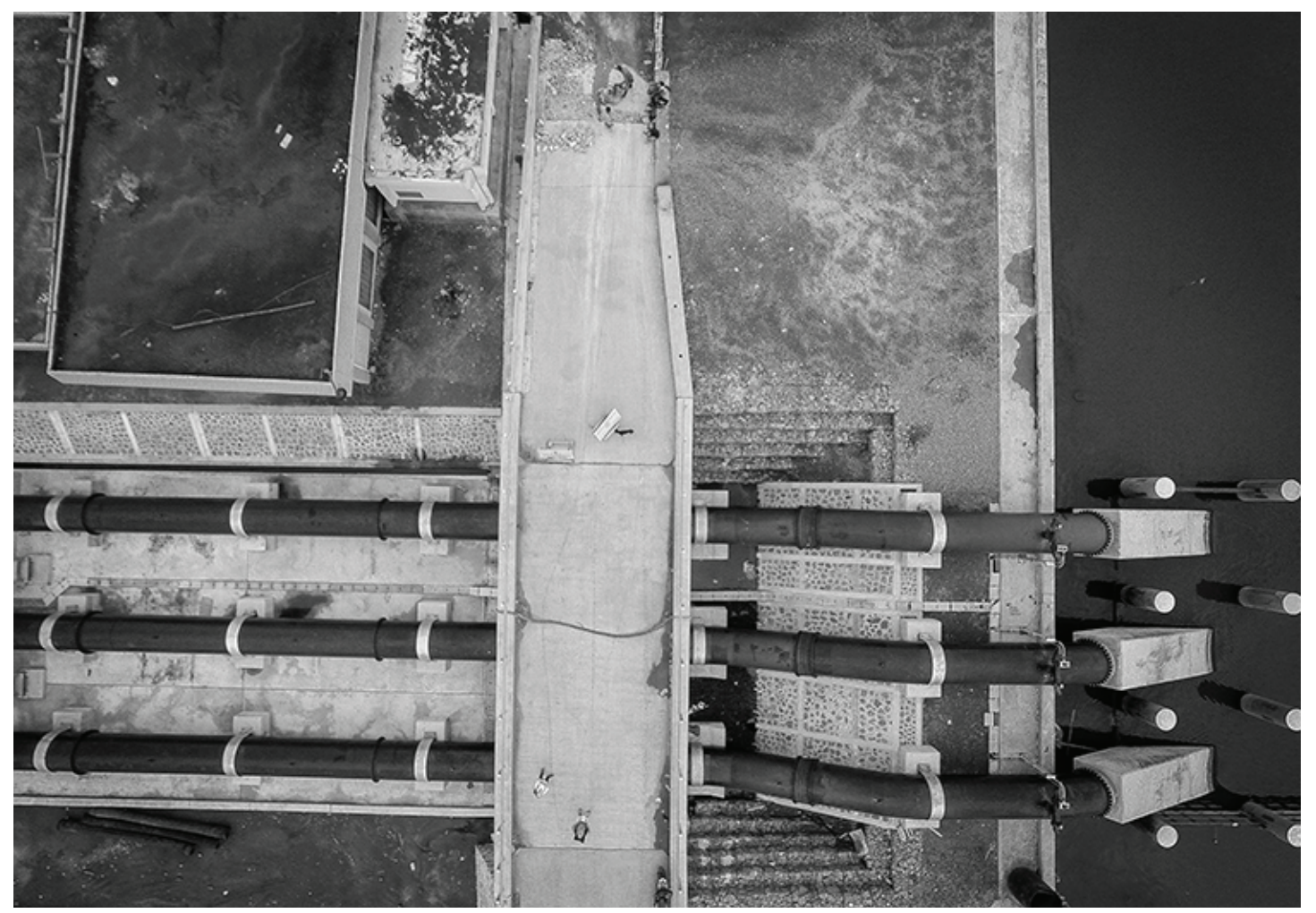

Figure 8. The Ciliwung River.

Due to Jakarta's high rate of development, large numbers of wells are drilled beneath the city to provide potable water. As more and more wells were drilled, the clay layers underlying the city began to subside. In 2007, it was discovered that parts of Jakarta are sinking at a rate of $200 \mathrm{~mm} / \mathrm{year}$-some of the highest rates of subsidence in the world (Deltares, 2013). Because of this land subsidence, the Ciliwung River can't drain naturally to the Java Sea. Instead, it must be pumped over the North Jakarta seawall by the Waduk Pluit Pump house through the three pipes shown. 


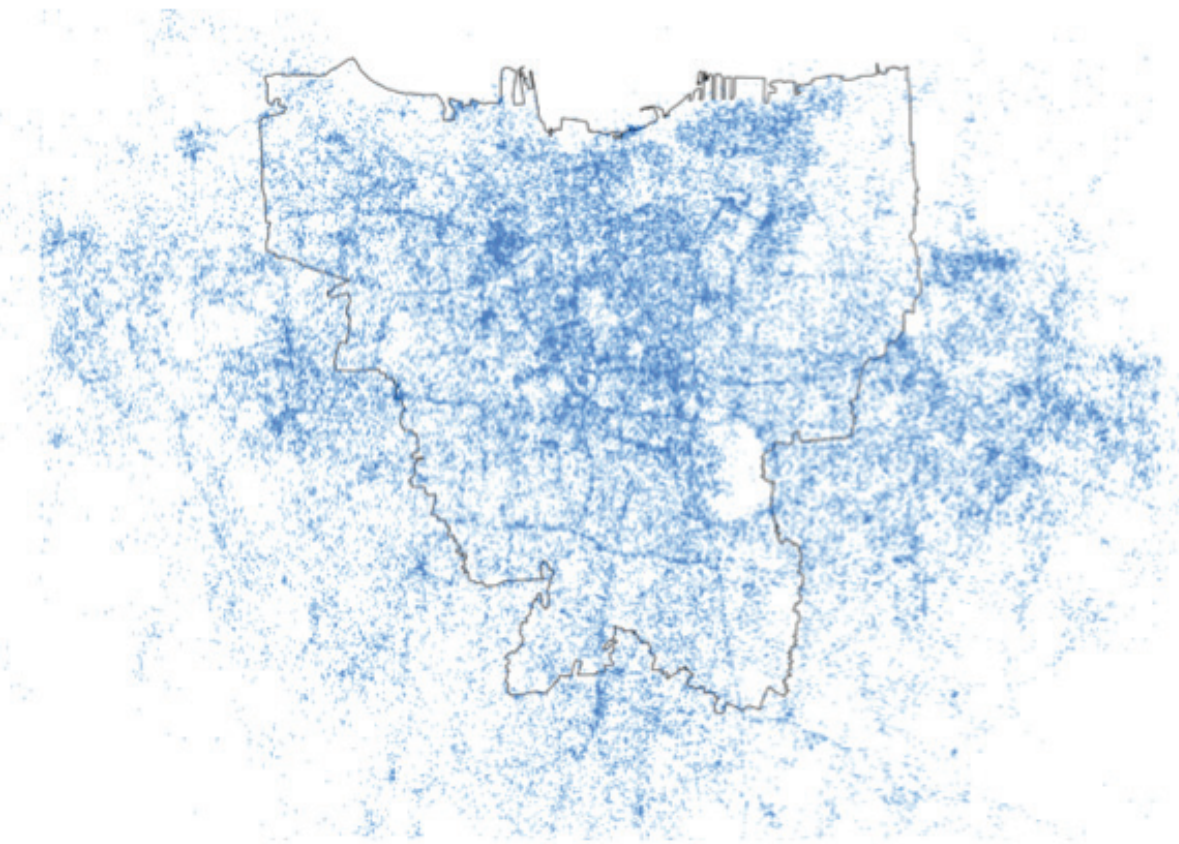

Figure 9. Tweeting about Flooding.

During the 2012-2013 flood season, over 12 million tweets were tweeted in Jakarta that contained the word "banjir"- "flood" in Indonesian. The spatial topology of the tweets reveals the structure of canals, roads, and other points of hydraulic infrastructure throughout Jakarta (Holderness et al., 2015). This topology suggests new ways to understand flooding and ultimately operate the hydraulic infrastructure.

Ultimately to begin considering novel approaches to the operation of hydraulic infrastructure, new sources of data are required. If we consider the probabilistic modeling of flooding and the subsequent operation of hydraulic infrastructure as drawing on historical data to make future predictions, then the opposite approach is to use real-time data to make real-time decisions. An example of this paradigm shift is the work in Jakarta by PetaJakarta.org, a research project led by the SMART Infrastructure Facility at the University of Wollongong in collaboration with the Jakarta Emergency Management Agency (BPBD DKI Jakarta) and Twitter, Inc. (Holderness et al., 2015).

In the "social media capital of the world," (Vishwani, 2012) PetaJakarta.org uses real-time data from social media to map flooding across the city in real-time (Figure 9). Not only does this real-time data allow for much quicker responses to the flooding from the residents and the government, but it also allows for the hydraulic 
infrastructure to be precisely operated as the flooding is evolving. Critically, the PetaJakarta.org system can detect infrastructure failure by noting spikes in social media chatter about flooding around pieces of hydraulic infrastructure when they fail. The ideas behind PetaJakarta.org present many new possibilities for the operation of hydraulic infrastructure based on real-time data.

As 21 st-century cities experience unprecedented flows of both people and water, the hydraulic infrastructure is increasingly strained to mediate this delicate, intimate relationship. But to ultimately move beyond our faulty, probabilistic based operation of hydraulic infrastructure and develop new, more efficient ways to manage flooding, we must admit that infrastructural failures are inevitable. As Jakarta demonstrates, distinct possibilities emerge when we acknowledge that flooding cannot be expected to follow topographical lines.

\section{Sources}

1. Adams, Ashley. The Floating Mass: Life Above a Liquid Landscape. 2016.

2. Baker, Judy L., "Climate Change, Disaster Risk, and the Urban Poor: Cities Building Resilience for a Changing World.” The World Bank. 2012.

3. Brakenridge, R, and E Anderson. "MODIS-Based Flood Detection, Mapping and Measurement: The Potential for Operational Hydrological Applications." Transboundary floods: reducing risks through flood management. 2006: 1-12.

4. Ceola, Serena, Francesco Laio, and Alberto Montanari. "Satellite nighttime lights reveal increasing human exposure to floods worldwide." Geophysical Research Letters 41.20. 2014: 7184-7190.

5. Deltares, "Sinking Cities: An Integrative Approach towards Solution." Deltares_Taskforce Subsidence. October 2013.

6. Desa, U. N. "World Urbanization Prospects, the 2011 Revision." New York: United Nations. 2011.

7. Detik. "Gulung Celana, SBY Pantau Banjir Sebetis Di Istana." Detiknews. January 17, 2013. Accessed March 17, 2016. http://news.detik.com/berita/2144681/gulung-celana-sby-pantaubanjir-sebetis-di-istana.

8. FMIS Team. "Jakarta Flood Management Information System. Appendix A, 54." 2012.

9. Haryanto, Ulma. "Breached Levee Leads to More Floods in Muara Baru | Jakarta Globe." Jakarta Globe. Accessed March 17, 2016. http://jakartaglobe.beritasatu.com/archive/breachedlevee-leads-to-more-floods-in-muara-baru/.

10. Holderness T., and E. Turpin. "PetaJakarta.org: Assessing the Role of Social Media for Civic Co-Management During Monsoon Flooding in Jakarta, Indonesia." SMART Infrastructure Facility, University of Wollongong, GeoSocial Intelligence Working Group White Paper 01. June 2015.

11. Inundation 3, "Sistem Alam dan Perkotaan." Jakarta, Indonesia July 2014. 
12. Nirmala, Ronna. "Jakarta Business District Floods After West Flood Canal Dike Collapses | Jakarta Globe.” Jakarta Globe. January 17, 2013. Accessed March 17, 2016. http://jakartaglobe. beritasatu.com/archive/jakarta-business-district-floods-after-west-flood-canal-dike-collapses/.

13. Tambun, Lenny. “Jakarta's Flood Problem Totally Solvable, for \$9.2b | Jakarta Globe.” Jakarta Globe. February 11, 2015. Accessed March 17, 2016. http://jakartaglobe.beritasatu.com/ news/jakartas-flood-problem-totally-solvable-9-2b/.

14. Taubenböck, $\mathrm{H}$ et al. "Monitoring urbanization in mega cities from space." Remote sensing of Environment 117. 2012: 162-176.

15. Turpin, Etienne, Adam Bobbette, Meredith Miller. Jakarta: Architecture + Adaptation. Jakarta: Universitas Indonesia, 2013.

16. Vaswani, Karishma. "Indonesia's Love Affair with Social Media-BBC News." BBC News. February 16, 2012. Accessed March 17, 2016. http://www.bbc.com/news/world-asia-17054056.

17. Yarista, Anjeng. "Research Published by PetaJakarta.org Intern Anjen Salma Yarista." Last modified January 15, 2016. https://info.petajakarta.org/2016/01/15/research-published-bypetajakarta-org-intern-ajeng-salma-yarista/ 